\title{
Effects of hyperglycemia and aging in angiogenesis and reepithelization of colonic anastomoses in rats ${ }^{1}$
}

\section{Efeitos da hiperglicemia e do envelhecimento sobre a angiogênese e a reepitelização de anastomoses colônicas em ratos}

\author{
Norton Luiz Nóbrega² ${ }^{2}$ Maria de Lourdes Pessole Biondo-Simões ${ }^{3}$, Daniel Barczak ${ }^{4}$, Sérgio Ossamu Ioshii ${ }^{5}$ \\ 1. Department of Experimental Surgery, Pontificial Catholic University of Paraná (PUCPR), Curitiba, Brazil. \\ 2. Master in Surgery, Pontifical Catholic University of Paraná (PUCPR), Brazil. \\ 3. PhD in Experimental Surgery; Associate Professor of the Surgery Department at Federal University of Paraná (UFPR); Professor of \\ Surgical Technique at PUCPR, Brazil. \\ 4. Medical Student at PUCPR, Brazil.. \\ 5. PhD in Pathologic Anatomy; Assistant Professor of Pathology at UFPR; Professor of Experimental Pathology at PUCPR, Brazil.
}

\begin{abstract}
Purpose: To evaluate angiogenesis and reepithelization of colonic anastomoses in rats. Methods: 82 Wistar rats, divided into: young normoglycemic, old normoglycemic and hyperglycemic. Diabetes was induced with streptozotocin. Glycemia was assessed before induction, at 24 hours and after 90 days, when a colotomy and an anastomosis were performed, assessed at days 3, 7, and 14. Samples were prepared by immuno-histochemistry (PCNA and antifactor VIII). Results: Mean glycemia after 90 days streptozotocin induction was 244,95 mg/dl. Day 7, reepithelization was greater in the young group than in the old normoglycemic $(\mathrm{p}<0.0001)$ and old hyperglycemic $(\mathrm{p}<0.0001)$ groups. Day 14 , the differences were significant between the young and old normoglycemic $(\mathrm{p}<0.0001)$ and old hyperglycemic $(p<0.0001)$ groups. The two old groups were not significantly different. At the three periods angiogenesis was higher in the young group than in the old normoglycemic $\left(\mathrm{p}_{3}=0.014 ; \mathrm{p}_{7}<0.0001 ; \mathrm{p}_{14}<0.0001\right)$ or the old hyperglycemic groups $\left(p_{3}=0.014, p_{7}<0.0001 ; p_{14}<0.0001\right)$. The old groups, day 3 , were not different $\left(p_{3}=0.627\right)$, but days 7 and 14 , angiogenesis was bigger in the normoglycemic group $\left(\mathrm{p}_{7}=0.042 ; \mathrm{p}_{14}=0.005\right)$. Conclusion: Age is important in reepithelization and angiogenesis of colonic anastomoses. Hyperglycemia interferes mainly in angiogenesis.
\end{abstract}

Key Words: Wound healing. Diabetes mellitus. Aging. Colon.

\section{RESUMO}

Objetivo: Avaliar a angiogênese e a reepitelização de anastomoses colônicas em ratos. Métodos: 82 ratos Wistar divididos em: jovens normoglicêmicos, velhos normoglicêmicos e hiperglicêmicos. Diabetes foi induzido com estreptozotocin. Glicemia foi medida antes da indução, após 24 horas e 90 dias, quando realizou-se colotomia seguida de anastomose, a qual foi estudada no 3. ${ }^{\circ}, 7^{\circ}$ e $14 .^{\circ}$ dia.Peças foram preparadas por imunohistoquímica (PCNA e Antifator VIII). Resultados: Glicemia média após 90 dias foi de 244,95 mg/dl. No 7. iaa, a reepitelização foi maior no grupo jovem que nos grupos velho normoglicêmico ( $<<0,0001)$ e velho hiperglicêmico $(p<0,0001)$. Dia 14, mantiveram-se as diferenças entre os grupos jovem e velhos normoglicêmico $(p<0,0001)$ e hiperglicêmico $(p<0,0001)$. Os dois grupos velhos não diferiram entre si. Nos três períodos a angiogênese foi maior no grupo jovem do que nos velhos normoglicêmicos $\left(\mathrm{p}_{3}=0.014, \mathrm{p}_{7}<0.0001 ; \mathrm{p}_{14}<0.0001\right)$ e que nos velhos hiperglicêmicos $\left(\mathrm{p}_{3}=0.014, \mathrm{p}_{7}<0.0001\right.$; $\left.\mathrm{p}_{14}<0.0001\right)$. No $3 .^{\circ}$ dia, os grupos velhos não foram diferentes $\left(\mathrm{p}_{3}=0.627\right)$, mas no $7 .^{\circ}$ e no $14 .^{\circ}$, a angiogênese foi maior no grupo normoglicêmico $\left(\mathrm{p}_{7}=0.042 ; \mathrm{p}_{14}=0.005\right)$. Conclusão: Idade é importante para a reepitelização e angiogênese das anastomoses colônicas. Hiperglicemia interfere principalmente na angiogênese.

Descritores: Cicatrização de feridas. Diabetes mellitus. Envelhecimento. Cólon. 


\section{Introduction}

Wound healing is a very complex process and, for this reason, it can be negatively impacted by several factors, including advanced age and diabetes, and often by the combination of both. Diabetes, through the nonenzymatic glycosylation mechanism, causes lesions in almost all kinds of tissues and can have a significant impact on the development of the healing process in colonic anastomoses by impairing its strength, the migration of inflammatory cells, thus delaying reepithelization and reducing the quality of collagen deposition and new vessel formation ${ }^{[1-5]}$. Old age has also been described as a hindering factor in the healing process. As for the gastrointestinal tract, studies show that anastomosis strength is preserved, while collagen deposition, migration of inflammatory cells, and reepithelization are changed ${ }^{[6-8]}$. This study aims to analyse reepithelization and angiogenesis of colonic anastomoses in young and old normoglycemic rats comparing them to old chronically hyperglycemic rats.

\section{Methods}

This study was performed after approval by the Ethics Committee on Animal Research of the Pontifical Catholic University of Paraná (PUCPR). It is in conformity with the 6.638 Federal Act and follows the standards of the Colégio Brasileiro de Experimentação Animal (COBEA) - affiliated to the International Council for Animal Laboratory Science. Eighty-two (82) Wistar male rats were used in the study, allocated in three groups, two of which with 21 animals and one with 40 animals. The two former groups were comprised of normoglycemic rats and the third one by hyperglycemic ones. In the first group, ages varied from 100 and 120 days, 113 on average, weight varying between 206 and 320 grams, 263 on average. In the second and third groups, ages varied between 740 and 760 days, 752 on average, and the weight varied between 276 and 430 grams, averaging to 340.2 grams. The rat groups, each containing 5 animals, were housed in polypropylene boxes of suitable size for the species. The light/dark cycle and the humidity rate were the same as the general environment's, with no artificial regulation, and the temperature was $20 \pm 2{ }^{\circ} \mathrm{C}$. The animals had free access to water and standard chow. The three initial groups of young and old animals were randomly subdivided into three sub-groups, according to an assessment time estimate - at days 3, 7, and 14 after the surgical procedure. The normoglycemic subgroups contained 7 rats, while the hyperglycemic contained 13 or 14 .

Before the experiment was initiated, all animals were weighed and each animal's glycemia was checked by collecting a drop of blood from the distal end of the tail after 12 hours of fasting. The animals in the hyperglycemic groups were injected intravenously with $50 \mathrm{mg} / \mathrm{kg}$ streptozotocin (Zanosar $®$; Upjohn CO) through the dorsal vessel of the penis. The rats in the normoglycemic groups received a corresponding volume of $\mathrm{NaCl} 0,9 \%$ solution through the same vessel. Twenty four hours after the diabetes induction, the rats injected with streptozotocin were measured for glycemia. After a period of 90 days immediately before the surgical procedure, each animal was checked again for glycemic level.

General anesthesia was performed via the intramuscular injection of $0,1 \mathrm{ml} / 100 \mathrm{~g}$ of a $1.0 \mathrm{ml}$ ketamine $(50 \mathrm{mg} / \mathrm{ml})$ with $1.0 \mathrm{ml}$ xilazine $(20 \mathrm{mg} / \mathrm{ml})$ solution. The surgical procedure consisted of a medial incision in the ventral abdominal wall measuring $4.0 \mathrm{~cm}$ and transverse colostomy at $2.5 \mathrm{~cm}$ from the peritoneal reflection. The bowel flow was reestablished through an end-to-end anastomosis, performed with a single extramucous plane, sutured with 8 stitches with monofilament nylon 6-0 thread, tied with 4 semi-knots. A $1.3 \mathrm{~cm}$ vascular anastomosis needle and a surgical magnifier were used for the anastomoses. A laparorrhaphy was performed and after anesthesia recovery; the rats were taken back to their boxes, where they stayed until the day scheduled for assessing the experiment. Euthanasia was performed through a lethal dose of ethylic ether.

The cavity was inspected for the presence of liquid, abscesses, peritonitis, adherences, as well as the organs involved. Next, an anastomotic segment of the colon, measuring approximately $4.0 \mathrm{~cm}$ was dissected. The specimen was open through the anti-mesenteric border and placed on filter paper strips. The prepared sample was then dipped into tamponated formalin (10\%) and taken for histological study. The specimens placed in paraffin were blocks from which 4-micrometers wide cuts were obtained, resulting in the preparation of 2 blades for each specimen. The cuts were stained by proliferating cell nuclear antigen immuno-cytochemical methods (PCNA) and antifactor VIII.

A $1,000 \times$ magnification optical microscope (immersion), combined with the Image Pro-Plus ${ }^{\circledR} 4.5$ version - Media Cybernetics program, was used to count positive and negative PCNA nuclei from 2 fields to the right and 2 to the left of the anastomosis line and 2 glandular crypts at the right and left of the samples, resulting in the positive and negative nuclei percentage, that is, both in replication and at rest. Each field had a $7,578.94 \mu^{2}$ area. For the PCNA analysis, reactions were considered positive whenever brown nuclei were detected, excluding probable bottom coloration areas.

A blood vessel count was conducted in the samples marked with antifactor VIII. The cytoplasmatic standard for this antibody allows identifying neovessels, stained red. Viewed under $400 \mathrm{x}$ magnification, a count of 3 fields for each histological cut above the anastomosis line was performed, from which an average was obtained. The area of each field analyzed was $46,330.63 \mu^{2}$.

The results were submitted to statistical treatment. Comparisons among groups and times of death were performed through a two-factor variance analysis: group and time of death. The groups were compared at each time of death and the times of death were compared within each group. The "t Student" parametric test was used to prove the hypothesis advanced in this experiment - for both independent and paired samples (the "Primer of Biostatistics" software program was used). The minimum significance level (significance probability) $\mathrm{p} \leq 0.05$ or 
$5.0 \%$ was adopted as the nullity hypothesis rejection level.

\section{Results}

Two deaths caused by anesthetic accident were registered in the old hyperglycemic group. The dosage of $50 \mathrm{mg} / \mathrm{kg}$ streptozotocin was efficient dosage to induce hyperglycemia (Figure 1).No peritonitis or abscesses were observed in any of the three groups. Adherences were found in all anastomosis, of different intensities; adherences to the spermatic funiculum, seminal vesicles, and small bowel loops.

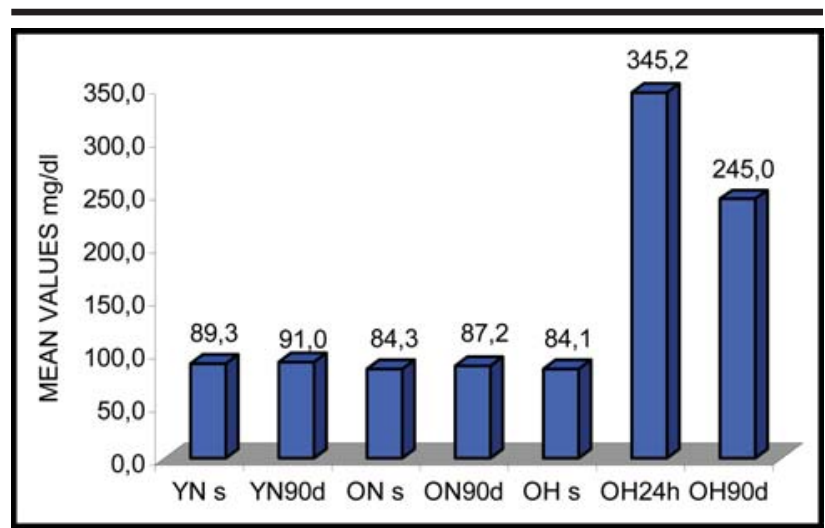

FIGURE 1 - Glycemic means in the three groups at the three periods of time studied $\mathrm{YNs}=$ young normoglycemic rats at start; YN90d = young normoglycemic rats after 90 days. ONs = old normoglycemic rats at start; ON90d $=$ old normoglycemic rats after 90 days. $\mathrm{OHs}=$ old hyperglycemic rats at start; $\mathrm{OH} 24 \mathrm{~h}=$ old hyperglycemic rats after 24 hours; OH90d = old hyperglycemic rats after 90 days

As for reepithelization, there was no significant difference, at day 3 after surgery, between the averages of positive PCNA nuclei in the three groups of animals. At day 7 after surgery, a higher positive PCNA nuclei mean was found in the young normoglycemic group in comparison with the old normoglycemic $(p<0.0001)$ and the old hyperglycemic $(\mathrm{p}<0.0001)$ groups. There was no significant difference between the old normoglycemic and hyperglycemic groups $(\mathrm{p}<0.0001)$. At day 14 after surgery, the positive nuclei mean differences were not statistically significant between the old groups, but was significant between the young normoglycemic group and the old normoglycemic group $(\mathrm{p}<0.0001)$ and between the young normoglycemic group and the old hyperglycemic group $(p<0.0001)$ (Table 1 and Figure 2). During the assessment of the number of vessels in the anastomosis area at day 3 , it was observed that the number of vessels was higher in the young normoglycemic rats group (5.44 mean), $29.6 \%$ higher than the old normoglycemic group's mean (3.83; $\mathrm{p}=0.014$ ) and $26.1 \%$ higher than the old hyperglycemic group's (4.02 mean; $p=0,014)$. The difference between the old normoglycemic group and the old hyperglycemic group was not significant $(p=0.627)$.
At day 7, the mean number of vessels was $25.49 \%$ higher in the young normoglycemic group (11.77 mean) in comparison with the old normoglycemic group (8.77 mean; $\mathrm{p}<0.0001$ ) and $35.17 \%$ higher than the old hyperglycemic group (7.63 mean; $\mathrm{p}<0.0001)$. The difference between the old normoglycemic and hyperglycemic groups was significant $(p=0.042), 13 \%$ higher in the normoglycemic group. At day 14, the groups presented the same behavior observed at day 7, that is, the number of vessels was $30.17 \%$ higher in young normoglycemic rats (11.27 mean) compared to the old normoglycemic group (7.87 mean; $\mathrm{p}<0.0001)$ and $43.66 \%$ compared to the old hyperglycemic (6.35 mean; $\mathrm{p}<0.0001)$. The difference between the old normoglycemic and hyperglycemic groups was $19.31 \%$ higher in the normoglycemic group ( $\mathrm{p}=0.005)$ (Table 2 and Figure 3 ).

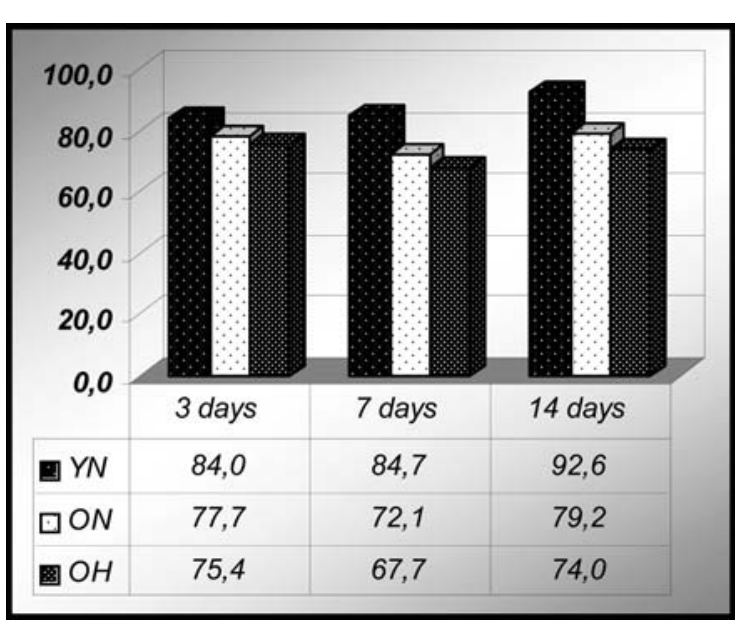

FIGURE 2 - Positive PCNA nuclei mean percentage in histological cuts of the colonic anastomosis performed on the animals studied in the three groups, at the three different periods of time. YN - young normoglycemic ON - Old normoglycemic $\mathrm{OH}$ - Old hyperglycemic.

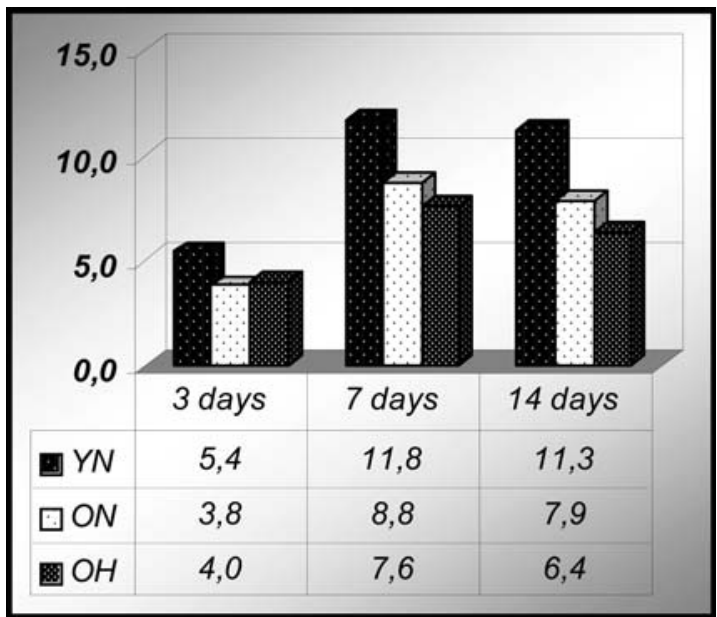

FIGURE 3 - Mean number of vessels in the anastomotic colon histological samples of the animals studied in the 3 groups at the three different periods of time. 
TABLE 1 - Positive PCNA nuclei percentage in the histological anastomosis samples of the three groups of animals studied at the 3 periods of time.

\begin{tabular}{|c|c|c|c|c|c|c|c|c|c|}
\hline & \multicolumn{9}{|c|}{ Percentage of positive PCNA nuclei } \\
\hline & \multicolumn{3}{|c|}{ Young Normoglycemic (YN) } & \multicolumn{3}{|c|}{ Old Normoglycemic (ON) } & \multicolumn{3}{|c|}{ Old Hyperglycemic (OH) } \\
\hline & Day 3 & Day 7 & Day 14 & Day 3 & Day 7 & Day 14 & Day 3 & Day 7 & Day 14 \\
\hline & 85,4 & 83,7 & 91,6 & 68,3 & 57,6 & 78,6 & 65,2 & 54,7 & 58,2 \\
\hline & 82,6 & 78,4 & 92,7 & 68,7 & 76,6 & 78,4 & 78,8 & 65,0 & 69,3 \\
\hline & 80,9 & 85,0 & 90,9 & 84,3 & 71,6 & 73,4 & 59,1 & 61,0 & 76,9 \\
\hline & 85,3 & 84,8 & 93,8 & 85,6 & 71,1 & 85,1 & 93,4 & 75,3 & 75,2 \\
\hline & 81,4 & 91,6 & 93,0 & 88,0 & 76,7 & 81,2 & 71,4 & 68,2 & 80,2 \\
\hline & 88,1 & 85,6 & 92,7 & 73,4 & 73,8 & 82,3 & 78,8 & 59,3 & 79,2 \\
\hline & 84,2 & 83,7 & 94,1 & 75,6 & 77,1 & 75,2 & 81,5 & 85,1 & 79,3 \\
\hline & & & & & & & 69,2 & 82,2 & 72,4 \\
\hline & & & & & & & 81,7 & 73,1 & 79,9 \\
\hline & & & & & & & 74,6 & 69,9 & 69,7 \\
\hline & & & & & & & 75,5 & 52,7 & 73,8 \\
\hline & & & & & & & 79,4 & 79,4 & \\
\hline & & & & & & & 71,6 & 58,7 & \\
\hline & & & & & & & & 63,3 & \\
\hline Average & 84,0 & 84,7 & 92,6 & 77,7 & 72,1 & 79,2 & 75,4 & 67,7 & 74,0 \\
\hline SD & 2,54 & 3,87 & 1,13 & 80,21 & 6,84 & 4,07 & 8,57 & 10,23 & 6,56 \\
\hline SD \% & 3,17 & 4,57 & 1,21 & 10,57 & 9,50 & 5,14 & 11,36 & 15,11 & 8,86 \\
\hline Minimum & 80,9 & 78,4 & 90,9 & 68,3 & 57,6 & 73,4 & 59,1 & 52,7 & 58,2 \\
\hline Maximum & 88,1 & 91,6 & 94,1 & 88,0 & 77,1 & 85,1 & 93,4 & 85,1 & 80,2 \\
\hline
\end{tabular}

t Student Test

TABLE 2 - Mean number of vessels, from 3 fields, at 3 periods of time, in the histological anastomotic samples in the 3 groups of animals studied

\begin{tabular}{|c|c|c|c|c|c|c|c|c|c|}
\hline & \multicolumn{9}{|c|}{ Vessels Mean } \\
\hline & YN.3 & ON.3 & OH.3 & YN.7 & ON.7 & ОН.7 & YN.14 & ON.14 & OH.14 \\
\hline & 5,0 & 4,0 & 3,3 & 9,6 & 7,6 & 7,3 & 11,0 & 7,0 & 6,6 \\
\hline & 3,6 & 3,3 & 3,6 & 10,3 & 7,3 & 7,6 & 11,6 & 8,6 & 6,3 \\
\hline & 4,3 & 4,3 & 3,6 & 12,3 & 8,6 & 7,3 & 10,3 & 7,6 & 7,6 \\
\hline & 5,3 & 5,3 & 4,0 & 13,0 & 9,0 & 7,0 & 12,0 & 7,6 & 6,3 \\
\hline & 6,3 & 3,3 & 4,6 & 12,6 & 10,0 & 6,6 & 12,0 & 8,3 & 5,6 \\
\hline & 6,6 & 3,6 & 3,6 & 11,6 & 9,6 & 7,6 & 11,0 & 9,0 & 5,6 \\
\hline & 7,0 & 3,0 & 4,3 & 13,0 & 9,3 & 7,0 & 11,0 & 7,0 & 6,3 \\
\hline & & & 4,3 & & & 7,6 & & & 6,0 \\
\hline & & & 4,0 & & & 7,3 & & & 5,3 \\
\hline & & & 4,0 & & & 8,3 & & & 6,6 \\
\hline & & & 5,0 & & & 8,3 & & & 7,6 \\
\hline & & & 3,6 & & & 8,0 & & & \\
\hline & & & 4,3 & & & 9,3 & & & \\
\hline & & & 7,6 & & & & & & \\
\hline Mean & 5,44 & 3,83 & 4,02 & 11,77 & 8,77 & 7,63 & 11,27 & 7,87 & 6,35 \\
\hline SD & 1,25 & 0,79 & 0,48 & 1,35 & 1,01 & 0,68 & 0,62 & 0,78 & 0,75 \\
\hline SD\% & 23,02 & 20,55 & 11,93 & 11,45 & 11,49 & 8,91 & 5,53 & 9,914 & 1,80 \\
\hline Maximum & 7,0 & 5,3 & 5,0 & 13,0 & 10,0 & 9,3 & 12,0 & 9,0 & 7,6 \\
\hline Minimum & 3,6 & 3,0 & 3,3 & 9,6 & 7,3 & 6,6 & 10,3 & 7,0 & 5,3 \\
\hline
\end{tabular}

t Student Test

YN.3 x YN.7 - p<0,0001; YN.3 x YN.14 - p<0,0001; YN.7 x YN.14 - p=0,390

ON.3 x ON.7 - p<0,0001; ON.3 x ON.14 - p<0,0001; ON.7 x ON.14 $-\mathrm{p}=0,086$

OH.3 x OH.7 - p<0,0001; OH.3 x OH.14 - p<0,0001; ОН.7 х ОН.14 $-\mathrm{p}=0,0002$

YN.3 x ON.3 - p=0,014; YN.3 x OH.3 - p=0,014; ON.3 x OH.3 - p=0,627

YN.7 x ON.7 - p<0,0001; YN.7 x OH.7 - p<0,0001; ON.7 x OH.7 - p=0,042

YN.14 x ON.14 - p<0,0001; YN.14 x OH.14 - p<0,0001; ON.14 x OH.14 - p=0,005

$\mathrm{YN}$ - young normoglycemic ON - old normoglycemic $\mathrm{OH}$ - old 


\section{Discussion}

Even though there are several studies on the aging process, few are geared to the effects of senescence on bowel tissue healing. In 1994, VERHOFSTAD et al. started a series of investigations on intestinal healing in diabetic rats induced by streptozotocin. They noticed that there was a higher incidence of intra-cavity and perianastomotic abscesses, particularly ileal. The bursting pressure was lower and the rupture occurred in the anastomosis line, even 7 days after surgery, different from the control rats, in which the burst occurred outside the anastomosis line. The decrease in anastomosis strength occurred as a result of a change in collagen's quality ${ }^{[3]}$. They reported that the transplantation of pancreatic islets, controlling hyperglycemia, prevented diabeteschanged wound healing ${ }^{[9]}$, and that preoperative glycemia control produced a more normal scar ${ }^{[4]}$. They also observed that high glucose levels in skin and fibroblasts culture medium did not result in specific differences in the absolute production of collagen, and that the administration of insulin stimulated the relative and absolute synthesis of collagen in the skin, but not in the ileum ${ }^{[5]}$. They reported microscopic changes and observed that in diabetic animals there was an increase in the number of polymorphonuclear cells at day 1 and 7 after surgery in colonic anastomoses. Reepithelization and collagen deposition were not changed ${ }^{[10]}$. Finally, they reported that anastomoses extracts of ileum and colon of diabetic rats at day 7 after surgery contained supra-normal levels of gelatinase enzyme activity, pointing at a high degradation potential of metalloproteinase in the matrix and, consequently, impaired anastomosis strength ${ }^{[11]}$.

BIONDO-SIMÕES observed that the colon healing had a particular character: more inflammatory infiltrate at day 3 after surgery, lower quantity of total collagen and type I collagen at days 14 and 21 after surgery, and reepithelization and angiogenesis were similar to those in young animals. Despite the fact that colonic anastomotic strength was higher in older rats at day 3 after surgery, that collagen concentration was higher in young rats' anastomoses at day 14 and 21 after surgery with higher type I collagen concentration, age alone did not interfere in the final result of the healing process ${ }^{[8]}$.

The waiting time for tissue exposure to hyperglycemia is also important. Before carrying out their studies, VERHOFSTAD et. al exposed their animals to hyperglycemia during periods ranging from 3 to 9 days. This can be considered too short a period of time, because the chronic effects of hyperglycemia cannot be observed yet, and also because during the first week of induction, the glycemic levels tend to be higher. The authors' justified such a short period of time as a way of preventing other factors such as nephropathy and diabetic angiopathy from occurring ${ }^{[3-5,9-11]}$. With the purpose of allowing for a longer exposition time, since diabetes is a slow progressive disease, in the present study, animals were kept hyperglycemic for 90 days before surgery. It can be observed that the hyperglycemic level remained high (mean of $244.95 \mathrm{mg} / \mathrm{dl}$ ), even though there was a drop (the mean glycemic level 24 hours after induction was $345.15 \mathrm{mg} / \mathrm{dl}$ ), pointing at a possibility of recovery of part of the beta pancreatic cells.

Reepithelization is an important process in tissue healing, because it separates bowel content from bowel wall tissue. Previous studies showed that reepithelization of skin wounds take place at a slower pace in older individuals ${ }^{[6]}$ and in trial animals ${ }^{[12]}$.

Studies show that reepithelization in skin wounds occurs at the same pace in young and old animals, and that colonic anastomoses behave in the same way as skin wounds ${ }^{[7]}$. VERHOFSTAD et al. showed that reepithelization in anastomoses of the ileum and colon occurs in a similar way in both normal and diabetic rats ${ }^{[10]}$. In the present study, it was observed at day 3 that there was no difference in reepithelization in the old normal and hyperglycemic groups $(\mathrm{p}=0.682)$. Upon comparison with the young group, it was observed that there was a tendency toward a higher mean number of positive PCNA nuclei and threshold probability, $\mathrm{p}=0,090$ and $\mathrm{p}=0,078$, respectively. At day 3 , the fact of being diabetic was of no significance $(\mathrm{p}=0.682)$. At day 7 , it was observed that age is a limiting reepithelization factor; in the young group it was $17.5 \%$ higher than in the old normoglycemic group, and $26.5 \%$ higher than in the hyperglycemic. The old groups did not show differences between each other ( $p=0.297)$. At day 14, the behavior was similar to that of day 7. Reepithelization in the older groups was similar $(p=0.154)$, even though it was $6.45 \%$ higher in the normoglycemic group. Both groups had lower reepithelization rates than the younger group, $14.6 \%$ lower in the old normoglycemic group $(\mathrm{p}=0.001)$ and $20 \%$ lower in the hyperglycemic ( $\mathrm{p}=0.001)$. It can be assumed from the data obtained from this study that the most important limiting factor to reepithelization at the periods of time studied $-3,7$, and 14 days - was age alone, and not so much its combination with diabetes. SEYERHANSEN et al., upon studying tissue healing in colonic anastomosis in old diabetic rats, also concluded that diabetes per se seems to have only a mild influence on colonic healing, even though the focus of their study was anastomoses strength ${ }^{[13]}$. In our study, maybe this fact has to do with a preexisting decrease of factors that stimulate reepithelization, such as older age.

Angiogenesis is part of the healing process that occurs simultaneously with matrix and fibroplasia formation. Several growth factors and cytokines are responsible for the proliferation of endothelial cells and derive mainly from platelets (PDGF) and activated inflammatory cells (EGF, VEGF). Most authors believe that aging has a negative impact on angiogenesis. Observation of mice showed lower Beta 1 transforming growth factor (TGF-b1) expression, lower growth factor derived from fibroblasts (FGF-2) and of the vascular endothelial growth factor (VEGF), which translates into significantly delayed angiogenesis ${ }^{[14]}$.

Diabetes is characterized by hindered microcirculation and by deficient angiogenesis, which contributes to frequent skin lesions and to a slow-down in tissue healing ${ }^{[15]}$. In the present study it was observed that, at day 3 , the mean vessel number found was higher 
in the young group compared to the old normoglycemic $(\mathrm{p}=0.014)$ and hyperglycemic $(\mathrm{p}=0.014)$ groups. At day 7 , the same behavior was observed, in which the mean vessel number in the young group (11.77) was significantly higher than in the old groups. The difference was $25.49 \%$ higher than in the normoglycemic group $(\mathrm{p}<0.0001)$ and $35 \%$ higher than in the hyperglycemic one $(p<0.0001)$. The old normoglycemic group's vessel mean was $13 \%$ higher than that of the hyperglycemic group ( $p=0.042)$. At day 14 , the same result was obtained, with the young normoglycemic group presenting a higher mean number of vessels. The difference between the old groups was $19.31 \%$ higher in the normoglycemic group.

This study allowed assessing the impact of factors such as age and hyperglycemia on tissue healing in colonic anastomoses. Recent research in this area highlights the potential importance of tissue growth factors in good tissue healing process development. New studies are required in order to identify the mechanisms by which these changes were produced and how they can be minimized or prevented.

\section{Conclusion}

Age is an important factor in reepithelization and in the angiogenesis of colonic anastomosis, and hyperglycemia interferes mainly in angiogenesis.

\section{References}

1. Fahey TJ, Sadaty A, Jones WG, Barber A, Smoller B, Shires GT. Diabetes impairs the late inflammatory response to wound healing. J Surg Res. 1991; 50 (4):308-13.

2. Witte MB, Barbul A. Repair of full-thickness bowel injury. Crit Care Med. 2003;31(8 Suppl), S538-546.

3. Verhofstad MH, Hendriks T. Diabetes impairs the development of early strength, but not the accumulation of collagen, during intestinal anastomotic healing in the rat. Br J Surg. 1994; 81(7):1040-5.

4. Verhofstad MH, Hendriks T. Complete prevention of impaired anastomotic healing in diabetic rats requires preoperative blood glucose control. Br J Surg. 1997; 83(12):1717-21.
5. Verhofstad MH, Bisseling TM, Haans EMH, Hendriks T. Collagen synthesis in rat skin and ileum fibroblasts is affected differently by diabetes-related factors. Int J Exp Path. 1998; 79(5):321-8.

6. Holt DR, Kirk SJ, Regan MC, Hurson M, Lindblad WJ, Barbul A. Effect of age on wound healing in healthy human beings. Surgery. 1992;112 (2):293-7.

7. Biondo-Simões MLP. Effects of aging in wound healing: evaluation of abdominal wall and colonic anastomoses, in rats. [Surgical Technique Professor Thesis]. Curitiba: Pontifícia Universidade Católica do Paraná; 2001.

8. Biondo-Simões MLP, Ioshii SO, Kimura L, Martynetz F, Lemos M. Effect of aging on the healing of colonic anastomoses in rats. Acta Cir Bras. 2004;19(2):89-93.

9. Verhofstad MH, Bocken JA, van der Vliet JA, Hendriks T. Pancreatic islet transplantation prevents impaired healing of intestinal anastomoses in diabetes. Transplant Proc. 1994; 26(2):660-1.

10. Verhofstad MH, Lange WP, van der Laak JAWM, Verhofsad AAJ, Hendriks T. Microscopic Analysis of anastomotic healing in the intestine of normal and diabetic rats. Dis Colon Rectum. 2001;44(3):423-31.

11. Verhofstad MH, Lomme RMLM, de Man BM, Hendriks $\mathrm{T}$. Intestinal anastomoses from diabetic rats contain supranormal levels of gelatinase activity. Dis Colon Rectum. 2002;45(4):554-61.

12. Swift ME, Kleinmann HK, Di Pietro LA. Impaired wound repair and delayed angiogenesis in aged mice. Lab Invest. 1999;79(12):1479-83.

13. Seyer-Hansen M, Andreassen TT, Oxlund H. Strength of colonic anastomoses and skin incisional wounds in old rats - influence by diabetes and growth hormone. Growth Horm IGF Res. 1999; (94):254-61.

14. Reed MJ, Vernon RB, Abrass IB, Sage EH. TGF-beta 1 induces the expression of type I collagen and SPARC, and enhances contraction of collagen gels, by fibroblasts from young and aged donors. J Cell Physiol. 1994;158 (1):169-79.

15. Singer AJ, Clark RA. Cutaneous wound healing. N Engl J Med. 1999;341(10):738-46.

\section{Correspondência:}

Norton Luiz Nóbrega

Rua Brasílio Itiberê, 3909

CEP 80240-060 Curitiba - Paraná - Brazil

Tel (FAX): 55 (41) 3343-6459

e-mail: nortonnobrega@uol.com.br
Conflito de interesse: nenhum Fonte de financiamento: nenhuma 